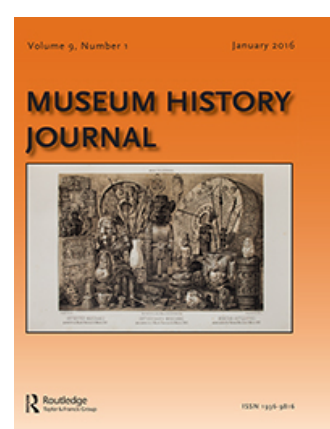

Museum History Journal

\title{
A Museum in the Heart of Amazonia: One Man's Laboratory
}

\section{Maria Margaret Lopes \& Magali Romero Sá}

To cite this article: Maria Margaret Lopes \& Magali Romero Sá (2016) A Museum in the Heart of Amazonia: One Man's Laboratory, Museum History Journal, 9:1, 77-92, DOI: 10.1080/19369816.2015.1118259

To link to this article: https://doi.org/10.1080/19369816.2015.1118259

曲 Published online: 14 Jan 2016.

Submit your article to this journal

III Article views: 63

View Crossmark data \lceil 


\title{
A Museum in the Heart of Amazonia: One Man's Laboratory
}

\author{
Maria Margaret Lopes \\ University of Brasilia, Brazil \\ Magali Romero SÁ \\ Fundação Oswaldo Cruz, Brazil
}

The Amazon Botanical Museum - Museu Botânico do Amazonas - opened in 1883 and closed in 1890 . Despite its brief life, the Museum was the first scientific institution in the Amazon Province of Brazil. Directed by the Brazilian botanist João Barbosa Rodrigues, the Museum aimed to be a modern institution similar to natural history museums in Europe and the United States. In addition to taxonomic studies of botanical and ethnographic collections collected in the Amazon region, the Museum also intended to develop studies in applied botany in medicine and industry. This article explores some aspects of the history of the Botanical Museum and examines the importance of Barbosa Rodrigues' individual agency in the Museum's organization and studies of the Brazilian Amazon. It also demonstrates that the Museum was fundamental to improving Barbosa Rodrigues' career as a botanist and ethnographer in the context of emerging Brazilian scientific communities of the period.

KEYWORDS Amazon Botanical Museum, João Barbosa Rodrigues, nineteenth century, Amazonia, Brazil

\section{Introduction}

In the last decades of the nineteenth century, Brazilian museums followed the unprecedented expansion of museums around the world, characterized as a true 'social movement'. ${ }^{\text {I }}$ This movement was marked by the specialization of the natural sciences and consolidation of field-based research which transformed 'ethnographic objects' into a specific category of studies. ${ }^{2}$ The sub-areas of zoological and botanical sciences and ethnographic and anthropological sciences acquired greater prominence in the research projects of general museums already existing in Brazil. The new museums which were subsequently established strived to specialize in and 
consolidate some or all of these fields. In the case of Brazil, museums were the main institutions responsible for research and institutionalization of these fields of knowledge, since only higher education courses in law, medicine, and engineering were offered at the time in some of the major cities in the south-east and north-east parts of the country. The expansion of Brazilian museums resulted either from government initiatives to modernize the country or from the initiatives of an emerging scientific community attempting to establish its own research programmes, practices, and professionalization of the natural sciences. ${ }^{3}$

The present-day National Museum was founded in I 8 I 8 in Rio de Janeiro (capital of the country), revived in 1876 , and thereafter remained as a general museum. In the north of the country, two museums were organized: the present-day Museum Paraense Emílio Goeldi, Belém, in the Province of Pará, in I 866, devoted primarily to zoology of the Amazon region; and the Amazon Botanical Museum in Manaus, in the Province of Amazonas in I883. In I894 in the south-east, in São Paulo, the Museu Paulista was established and specialized in South American neo-tropical fauna; and in the south a regional institution, the Paranaense Museum, was founded in Curitiba in 1874 , which resulted from the city's participation in local, national, and international exhibitions. Several private and small museums were created, and exhibitions took place, around the country. In the north-east region, local museums - associated associated with historical and geographical institutes - were organized for natural, ethnographical, and archaeological collections, and historical documents in cities such as Fortaleza, Alagoas, Recife, and Salvador. ${ }^{4}$ These museums contended with each other for institutional and professional prominence, particularly with the Rio de Janeiro National Museum, which throughout the nineteenth century remained the country's main scientific institution in relation to natural sciences and ethnography. ${ }^{5}$

Of these museums, the Amazon Botanical Museum was the only one that disappeared, just seven years after its creation. Like the vast majority of international studies on the history of museums, Brazilian historiography has also centrally attended to those museums that corresponded to ideals of permanence or long duration. The lack of archives and the nearly impossible task of tracking lost collections also complicate the task of enquiring into museums that no longer exist. Despite these impediments, and supported by official documents, publications, and articles from local newspapers, this article argues that the Amazon Botanical Museum contributed significantly to the knowledge of natural history and ethnography of the Amazon region, together with the present-day Museu Emilio Goeldi in Belém do Pará. The Amazon Botanical Museum can also be considered an exemplary case study of a promising museum in the Amazon jungle that was lost due to the shortsighted interests of the ruling elites and the particular objectives of its founder. Based on the short-lived existence of this institution, which continues to be one of the least known and investigated Brazilian museums, this paper aims to more fully understand how naturalists, who also served as ethnographers and museum curators, used the institutional form of the museum to pursue their scientific interests.

The founder of that museum, João Barbosa Rodrigues (I 842-I909), is exemplary of Brazilian naturalists who devoted their professional lives to safeguarding and studying the ethnographic collections representing thus far unknown indigenous 
nations which were being decimated by the government's land-use policy and occupation of their areas. Barbosa Rodrigues was a polemical, ambitious, and intelligent figure in the scientific circle of the court of Rio de Janeiro, where he engaged in several controversies with the directors of the Rio de Janeiro National Museum. Barbosa Rodrigues fought fiercely to become part of the Brazilian scientific community and to achieve international recognition. He was born in Rio de Janeiro on 22 June 1842 , his father a Portuguese merchant and his mother of indigenous ancestry. He was raised in Campanha, in the province of Minas Gerais, and it was there that he began his studies in sciences and arts. In the I 850 , after returning to the capital, he attended the Commercial Institute of Rio de Janeiro, later becoming the secretary of this institution. ${ }^{6}$ During this time he became friends with Guilherme Schüch, Baron of Capanema (I 824-I908), a mining engineer linked to the Brazilian imperial family. ${ }^{7}$ Capanema became Barbosa Rodrigues' patron and supported his work as a secretary and design teacher at the Pedro II College, a traditional college in the Brazilian court. Barbosa Rodrigues was later commissioned to undertake expeditions in the Amazon before founding the Amazon Botanical Museum. His artistic ability, together with his enthusiasm for botany and the encouragement and support of Capanema, eventually made Barbosa Rodrigues a botanist. ${ }^{8}$

The paper thus outlines how the Amazon Botanical Museum was shaped into an institutional locus of scientific authority for the personal activities of its director, despite its chronic lack of funding and his complex relationship with local politicians. The local authorities did not effectively support the creation of the museum and considered Barbosa Rodrigues, who came from the capital of the Brazil, as a foreigner in his own country. Intertwining museums and biographies, ${ }^{9}$ the paper argues that the museum was instrumental in launching the botanist's career such that, after the Amazon Botanical Museum closed, Barbosa Rodrigues was able to move to the much larger and better financed Botanical Gardens of Rio de Janeiro where he could more successfully pursue his research. ${ }^{\text {Io }}$

\section{An ambitious proposal}

The Amazon Botanical Museum - Museu Botânico do Amazonas - was created on 18 June 1883 , in the former island of Caxangá (now known as Manaus) at the initiative of Barbosa Rodrigues. He had already been commissioned to explore the Amazon valley between I872 and I875 and was designated director of the Museum after his plan was approved by the imperial government of Rio de Janeiro, thanks to the support of Capanema. Barbosa Rodrigues was already known as a botanist and ethnographer in the scientific circles of Rio de Janeiro and also in the north of the country. ${ }^{\text {II }}$ The Museum proposed by Barbosa Rodrigues was intended as an institution for botanical, archaeological, and ethnographical studies in Amazonia. A local museum, it was destined to specialize in the study of botany applied to medicine and industry, along with chemical analyses and material extraction for physiological and therapeutic experiments. As Museum Director, Barbosa Rodrigues had the regions of the Amazon forest at his disposal as a field of endless possibilities for his studies. 
The plans drawn up by Barbosa Rodrigues included, for exchange with international scientific societies, the publication of a museum journal written in Portuguese and French containing descriptions of new plants and archaeological and ethnographical studies of the Amazon. ${ }^{\mathrm{I2}}$ The journal, Vellosia - Contribution of the Amazon Botanical Museum, paid homage to Friar Velloso, a botanist of the Brazilian colonial period. Three volumes (one with images) were printed from I 885 to I 888 and reprinted in I89I, with additional papers by Barbosa Rodrigues on the description of newly discovered orchids and palm trees, texts on palaeontology and archaeology, as well as institutional documents. ${ }^{{ }^{3}}$ Following his plans, Barbosa Rodrigues organized the Museum into three sections - Botany, Chemistry, and Ethnography - and added a botanical garden to cultivate, conserve, and exhibit plants. The Botany Section was responsible for the collection, classification, and preparation of specimens according to modern herbarium practices. The catalogue of the collection included entries for the ordinary and scientific names, and the main characteristics of each plant. Duplicate catalogues were to be sent abroad for exchange for other institutions' catalogues, because international cooperation was considered one of the Museum's priorities. ${ }^{\text {I4 }}$ The Chemistry Section was used as a laboratory to identify the organic properties of the plants, as well as the medicinal or industrial uses of oils, gums, fibres, and so on. The Ethnography Section kept objects, photos, and drawings representing the indigenous people engaging in activities useful for anthropological studies. In order to secure the objects of indigenous people for his studies, Barbosa Rodrigues emphasized that no object could leave the Museum, except for exchange, and only after the Museum had a triplicate. ${ }^{\mathrm{I} 5}$

The Museum was officially inaugurated on I6 February I884. ${ }^{16}$ Although Barbosa Rodrigues presented a plan for a purpose-built museum building, it was never constructed and in its short existence the Museum occupied three different buildings in Manaus: Caxangá (February I 884-July I 885 ); ${ }^{\mathrm{I7}}$ an old hospital in the São Sebastião neighborhood (July I885-July I886) and Liceu Amazonense (July I 886-г 890), in the downtown area of Manaus. The first collections exhibited in Caxangá included botanical and ethnographic specimens that were mainly the result of Barbosa Rodrigues' expeditions to the Amazon valley. ${ }^{\mathrm{I} 8}$ In addition to these collections, there were others that had been brought from the Urubu River, a large rock with indigenous drawings from a region known as Lages, and another one which had been unearthed during the construction of the new market in Manaus. ${ }^{\text {I9 }}$

Among Barbosa Rodrigues' first tasks as Museum Director, a month after the inauguration of the Museum, was to begin several expeditions which continued through I 885 to the Jauapery River (not yet explored) in order to investigate natural resources and to befriend the natives of the region - the Crichinás who were still little known. ${ }^{20}$ This indigenous people was accused of threatening small villages populated by others in their region. Since his first trips there in I 873, Barbosa Rodrigues had been interested in studying these peoples. One of the first problems Barbosa Rodrigues faced was with members of the clergy in charge of evangelizing the natives. The clergy tried to prevent his expeditions because it feared losing control over the Crichinás. The clergy acknowledged 
that Barbosa Rodrigues was a professional botanist, but believed his mission to befriend the natives of the region was the Church's prerogative. ${ }^{2 \mathrm{I}}$ Despite opposition from the clergy and provincial representatives who supported it, the expeditions had the backing of the President of the Province and were carried out. These expeditions resulted in 2000 'new acculturated natives' and a great number of objects for the Museum. The expeditions were a milestone in Barbosa Rodrigues' career; he went on to publish one of his most important works on these indigenous peoples. ${ }^{22}$

After the expeditions concluded in $\mathrm{I}_{8} 88_{5}$, the local government accepted Barbosa Rodrigues' requests to better accommodate the new collections he had gathered and those the Museum already possessed but that were deteriorating due to its lack of staff. The local government transferred the Museum to its second building, a temporary hospital built in the São Sebastião neighbourhood to counter a smallpox epidemic. The Museum was open for visits on Sundays. The ground floor housed the chemistry laboratory and the library and the collections were accommodated in rooms on the upper floor. ${ }^{23}$ Nevertheless, there were endless problems; for example, no running water for the Botanical Garden. The staff shortage was never solved. ${ }^{24}$ Despite the difficulties, the Museum opened in its São Sebastião location on 29 July I 885 . The ten rooms of the museum were minutely described in the newspapers: spacious rooms were dedicated to ethnography and archaeology where four large cabinets full of indigenous objects were distributed. The cabinets and walls exhibited weaponry, arrows, loin-cloths, sandals, necklaces, earrings, earthenware, and a multitude of domestic wooden and straw utensils from several indigenous nations such as the Crichanás, Tucanos, Parintintins. The other cabinets displayed Tikunas cloths and masks and Campas arrows and skulls found in the Purus River, and stoneware from the provinces of Minas Gerais (regions that Barbosa Rodrigues had also surveyed before arriving in Manaus). As a whole, the Museum's ethnographic collections represented sixty-one indigenous nations of the Amazon valley which, the newspapers praised, 'no other Museum could equal'. ${ }^{25}$ They amounted to I IO3 objects which also included some photographs and drawings that were meticulously described in the Museum's catalogue (Figure I). ${ }^{26}$

The catalogue was organized according to the cabinets. The sixty-one indigenous nations were named in the 'List of Savage Tribes represented in the museum' Relação das tribus selvagens representadas no museu - in a geographical classification according to the river banks they inhabited. The catalogue had 464 entries, stressed that most of the acquisitions had been collected by the director on his expeditions, and listed some fifty donors. ${ }^{27}$ The catalogue also provides crossreferences to the many works Barbosa Rodrigues used to describe the objects. For instance, an Amazon idol plaster model was related to one of Barbosa Rodrigues' archaeological publications which had major international repercussions. ${ }^{28}$

The botanical rooms were the Director's privileged work spaces. The museum herbaria included I 28 I species from 78 families and 322 genera, with some 5000 specimens classified and organized by Barbosa Rodrigues, who considered 56 species which he drew and described - as new to science. The Museum received collections from Mexico, Chile, and some 800 samples from California, donated by the botanist 


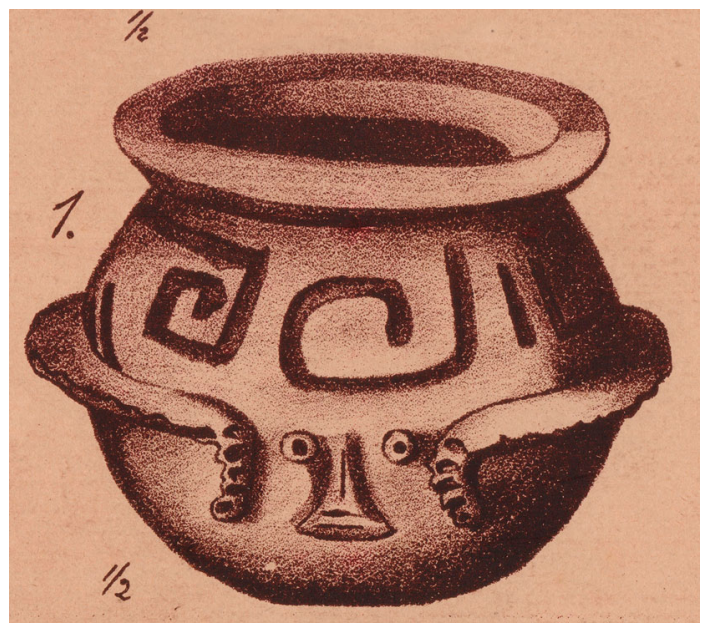

FIGURE 1 Brazilian Indians artefacts. Burial urn collected on the banks of the Amazon river. Vellosia, vol. 4, estampas archaelogia, paleontologia, 1885-1888 (Rio de Janeiro: Imprensa Nacional, 1891).

Courtesy of the Library of the Botanical Gardens of Rio de Janeiro. Reproduced with permission.

John Donnell Smith (I829-I928) according to a report of the President of the Province. $^{29}$

In the year following the Museum's inauguration, the Botanical Garden was opened to the public, and in February I 886 the Chemistry Laboratory was inaugurated and equipped with several devices purchased from Fontaine, in Paris, ${ }^{30}$ a supplier of several European scientific institutions. The chemist hired for the Laboratory was Franz Pfaff (n.d.) from Geneva. ${ }^{3 \mathrm{I}}$ On 29 July I 886, 'The First Exhibition of the History of the Province' was opened. The exhibition was modelled on a larger one in Rio de Janeiro in I88I - 'Exhibition on the History of Brazil'. ${ }^{22}$ Until then, no other province had displayed an exhibition related to its history. The Museum exhibition, including collections of maps, provincial newspapers, and old Brazilian coins, remained open to the public every day from 8 am to $5 \mathrm{pm} .{ }^{33}$ At the time Barbosa Rodrigues was also busy writing publications, and preparing and sending specimens to the South American Exhibition organized regularly by the Commercial Geographical Society in Berlin in order to enhance trade relations between the countries. ${ }^{34}$

In those years, the Museum worked regularly with and had benefited extensively from the large number of specimens collected during the Director's expedition to the Crichanás. However, two years later, in July I 888, with a new Vice-Provincial President, the Museum, which occupied ten rooms, was moved into a single dark storage room within the new building of the Liceu Amazonense (now the Colégio Amazonense Dom Pedro II, in downtown Manaus), under the pretence of budget constraints and in the context of local power struggles. The relocation also temporarily separated the Chemistry laboratory from the Museum. ${ }^{35}$ With a new turn of politics that same year, now in favour of the Museum, the collections were moved from the single storage room to a bigger and better space at the Liceu Amazonense. According to Barbosa Rodrigues' detailed description, ${ }^{36}$ the Museum was allocated laboratories, six large rooms, and two large glassed balconies for displays, all adjacent to noble points of entry at the front and on the left side of the building. The 


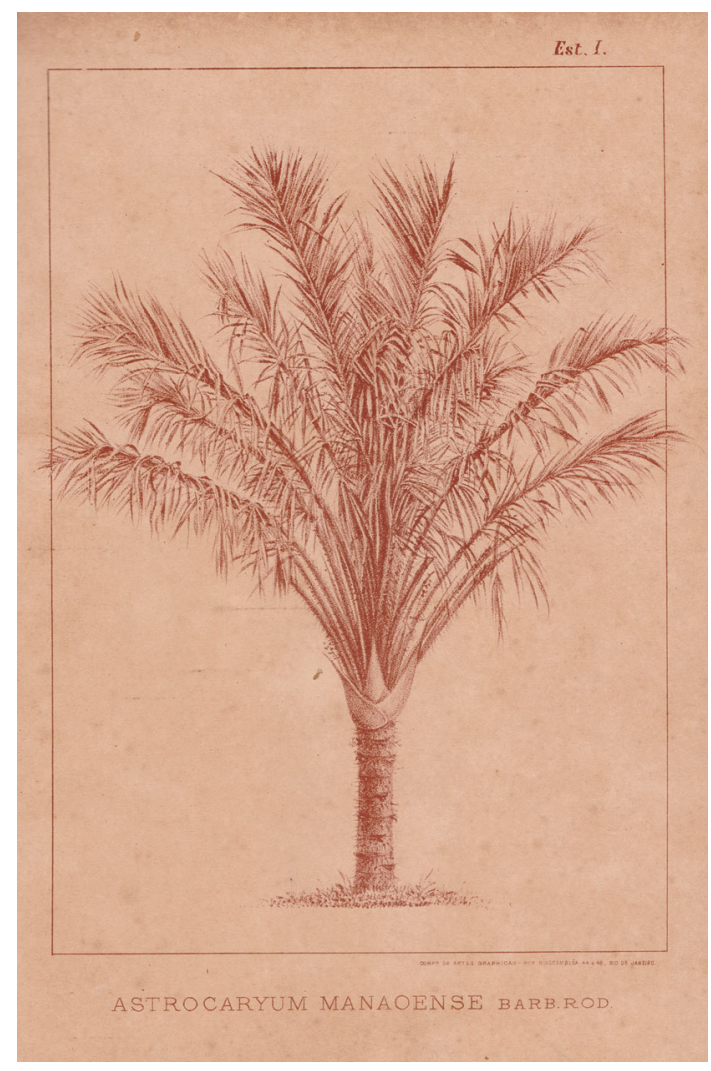

FIGURE 2 Astrocaryum manoense. A new species of palm tree described by Barbosa Rodrigues from the Rio Negro, Manaus. Vellosia, vol. 3, estampas botânica,1885-1888 (Rio de Janeiro: Imprensa Nacional, 1891). Courtesy of the Library of the Botanical Gardens of Rio de Janeiro. Reproduced with permission.

rooms with the archaeological collections were spacious and allowed the cabinets of the old exhibition to be rearranged. The centre of one room held two large wood canoes from the Pomaris and the Uapés, a large Tikuna utensil used to prepare manioc, which had been acquired by the director in another expedition to the Javari River in I886, and on a table the iliac bones of the 'colossal turtle' Emys macrococcygeana - and a Purussaurus fossil, the 'gigantic saurian' described by Barbosa Rodrigues in the Vellosia. ${ }^{37}$

The Botanical Section held Barbosa Rodrigues' inventory of Amazon flora, an example of his continuing interest in describing new species of palm trees and orchids, his highest priorities among the botanic groups (Figure 2). The section also contained eight large cabinets with roo green-painted boxes containing the Museum's herbaria, classified by species and family, according to De Candolle subclasses. There were tools and chemicals for plant studies and for microscopic analysis, tables for preparing specimens, with presses and paper for drying samples. ${ }^{3}$ The Chemistry laboratory was reorganized in I 889 , with a photography dark room and piped gas. It had all the instruments required for the chemical analysis of the plants - from pipettes to the apparatus for plant electricity studies, a cage vitrée for toxic substances, a Carré ice-making machine, and so forth. Barbosa Rodrigues thoroughly listed each piece of equipment, one by one, in Vellosia, an accounting 
necessitated by the disarray and damaged materials he found when the laboratory was returned to the Museum. ${ }^{39}$

In April I 890, Barbosa Rodrigues gave up his ambitious plans for the Botanical Museum and accepted an invitation to direct the Botanical Garden of Rio de Janeiro. Despite his initiatives, the Museum never became the modern research institution for which he had striven. In his last report to the President of the Province, Barbosa Rodrigues reiterated requests for more funds, equipment, and personnel for the Museum. ${ }^{4}$ When it was closed in I 890 , its only full-time employees were the director and a doorman. By that point the rest of the Museum's staff was comprised of Barbosa Rodrigues' family. The Botanical Museum had become a typical family endeavour, as were other collections of similar importance in Latin America. ${ }^{4 \text { I }}$ Barbosa Rodrigues' son-in-law was the Museum's secretary for a while, and one of the director's thirteen sons helped to identify a new species. Dona Constança Eufrosina da Borba Pacca Barbosa Rodrigues (I844-I920), the director's third wife, played a central role in the Museum's maintenance and in Barbosa Rodrigues' expeditions, the preparation of his illustrations, and even in scientific papers - though they did not include her name. Instead, she was rewarded with the naming of new species of orchids and palm trees after her by her husband, such as Bactris constanciae. ${ }^{42}$

When Barbosa Rodrigues left the Amazon and the Museum was formally discontinued, he reported that the Botanical Museum held I 260 ethnographic objects, more than I0,000 botanical specimens and more than 500 devices in the chemistry section. ${ }^{43}$ Officially, the objects of the extinct museum became the responsibility of the Amazon Public Education Bureau. Some years later the Bureau reported that the ethnography and archaeology cabinets had been dismantled; there was no reference to the botanical collections. ${ }^{44} \mathrm{~A}$ part of what was once the Museum library survived in the library of the Liceu Amazonense. Years later it was transferred to INPA (Instituto de Pesquisas da Amazonia), the Amazon Research Institute founded in I954. In I980, a single specimen representing the species Tynanthus ignei, that Barbosa Rodrigues had described, was found and kept in the INPA herbarium as a rarity. The INPA library retained books such as Martius' Flora brasiliensis, de Candollés Prodromus, works by D'Orbigny, Lineu, Buffon, and volumes of Adansonnia, and several of these volumes still display the stamp: MUSEUM. ${ }^{45}$

\section{The museum as laboratory}

The research that launched Barbosa Rodrigues' field-based research and led him to create a museum began with orchids in I 868 in Minas Gerais. The Swedish doctors and botanists Salamon Eberhard Henschen (I847-1930) and Anders Fredrick Regnell (I807-I884), who were also collectors and experts on orchids, introduced Barbosa Rodrigues to their studies. His command of languages, especially Latin, intuitive grasp of taxonomy, as well as his skills as a scientific illustrator, were instrumental to Barbosa Rodrigues' botanical learning. His first major work on orchids, an illustrated manuscript in three volumes, remained unpublished due to the lack of support from the Brazilian scientific community of that period. ${ }^{46}$ The manuscript 
was analysed in 1877 by the German botanist Heinrich Gustav Reichenbach (I 823I 889), at the time considered a leading expert in orchids, who had been invited to write the orchid section of Flora Brasiliensis, then the biggest undertaking on the flora of Brazil. ${ }^{47}$ Reichenbach considered Barbosa Rodrigues's specimen descriptions to be 'parfaites', but believed that half had already been described and offered to co-publish just Barbosa Rodrigues' new discoveries. ${ }^{48}$ Barbosa Rodrigues rejected the invitation, and it was only in 1892 , with his botanical studies consolidated and after intense negotiations with the Belgian botanist Célestin Alfred Cogniaux (I84I-I9I6), then responsible for the orchids section of Flora, that Barbosa Rodrigues finally agreed to participate in it. Flora Brasiliensis contained 267 copies of Barbosa Rodrigues' original drawings and 70 genera and 538 species described by him. ${ }^{49}$

Barbosa Rodrigues continued his research on orchids at the Botanical Museum along with other findings yielded by his first expeditions to the Amazon valley between 1872 and 1875 . In addition to five extensive reports about the expeditions, Barbosa Rodrigues initially published only the descriptions of some new plant species. ${ }^{\circ}$ Between 1886 and I 888 , in the Botanical Museum, Barbosa Rodrigues illustrated at least 394 details of various plants and 94 ethnographic objects. ${ }^{5}$ Among other works, Barbosa Rodrigues published Eclogae plantarum novarum; the third volume of the series Palmae Amazonian novae and Genera et species Orchidearum novarum..$^{52}$ The latter text amplified his earlier works, which now included 700 species distributed in 85 families comprising 225 genera. Of these, Barbosa Rodrigues affirmed that 105 species and 4 genera were new and had been discovered and classified by him, and the material was assembled in the herbarium of the Botanical Museum. ${ }^{53}$

During his years at the Botanical Museum Barbosa Rodrigues also resumed his studies on curare. The curare was part of the rhetoric which Barbosa Rodrigues used to justify the creation of the Museum. In his Museum plan of I883, Barbosa Rodrigues emphasized how much it - in other words, his own study - would contribute to the advancement of scientific research on curare, well known among the indigenous people of the Amazon. ${ }^{54} \mathrm{He}$ had learned how to manipulate curare with a Miranha Indian, and from 1878 to 1903 his hypothesis about the origin of the venom was considered correct, though he was wrong about the antidote. While at the Botanical Museum, Barbosa Rodrigues published a new paper, Década de Strychnos Novos, ${ }^{55}$ with the description of ten new species of Strychnos, where he continued to attribute the toxicity of the venom to these species alone. ${ }^{56}$ It was also during this period in the Museum that Barbosa Rodrigues published the result of his analyses conducted in the laboratory of the Museum, with the assistance of the chemist Pfaff, on the new species of the order of Ternstroemiaceae. ${ }^{57}$

Ethnographic and archaeological studies were another focus of attention for Barbosa Rodrigues while at the Botanical Museum. He was the first Brazilian naturalist to study archaeological relics such as a zoomorph carved rock - an Amazon idol - he found on the shore of Paru-Amoi, in the lower Amazon, during his first expeditions in the I870s. To him, the object was made of nephrite or jadeite, not found in Brazil but abundant in Asia. Barbosa Rodrigues therefore claimed an Asiatic origin for his finding, implying a migration of Asian peoples to the Americas 
and thereby provoking a dispute with Ladislau Netto (I838-I 894), Director of the Museu Nacional from I875 to I893, who claimed the artefacts originated in the Americas. ${ }^{58}$ Barbosa Rodrigues's work of the 1870 os was favourably reviewed by Enrico H. Giglioli (I845-I909), president of the Società Italiana di Antropologia e di Etnologia. ${ }^{59}$ Barbosa Rodrigues also won the support of the director of the Museum of Prehistory and Ethnography of Freiburg, Leopold Heinrich Fischer (I 8I7-I 886), with whom Barbosa Rodrigues had exchanged letters since I 878 and who agreed with the latter's Asian-migration hypothesis. ${ }^{60}$ Plaster models of the Amazon idol exhibited in the Botanical Museum were sent to museums in Berlin, Baden, Freiburg, and Munich. ${ }^{\text {I }}$ Barbosa Rodrigues' interests in archaeology increased while at the Botanical Museum, and he investigated collections of sambaquis, lithic materials, ceramics, including funerary urns, to support his theory. ${ }^{62}$

We have no estimates of the Amazon Botanical Museum's public during its existence, but clearly it served as Barbosa Rodrigues' private workplace. The Museum's seven years were extremely productive for the director: Barbosa Rodrigues not only produced drawings of plants and ethnographic objects, published catalogues for exhibitions and news for periodicals, but also published many of his main scientific papers - at least eleven of fifty-two papers. ${ }^{63}$ Other works published later were surely prepared in the Museum or were the result of his investigations during that period, for instance Muyrakytan and Symbolic Idols, sketched in Manaus in I 889 and reprinted in Rio de Janeiro in 1899 , where he reaffirmed his studies on the Asian origins of the Amazon civilization. ${ }^{64}$

\section{After the Amazon Botanical Museum}

Research conducted while directing the Amazon Botanical Museum was decisive in Barbosa Rodrigues' invitation to direct the Botanical Garden of Rio de Janeiro and in consolidating his standing among experts on Brazilian flora. In 1903, after Barbosa Rodrigues had taken up his position in Rio de Janeiro, he was able to finally publish his important work Sertum palmarum brasiliensium. As evidence of his national and international recognition, Barbosa Rodrigues listed on the cover of this work, which crowned his career, the institutions in which he was accepted. In addition to listing the Botanical Garden, Historical and Geographical Institute and Polytechnic Institute of Rio de Janeiro, and his designation as vice president of honour of the 2nd Latin American Scientific Congress in Montevideo in I90I, he also mentioned: the Academy of Sciences of Lisbon, the Institute of Coimbra, the Royal Botanical Societies of Vienna and Brussels, the Botanical Societies of Marseille and Edinburgh, the Society of Naturalists of Freiburg, and the Anthropological and Ethnological Society of Florence. ${ }^{65}$

Through his denominations of palm trees in Sertum palmarum brasiliensium Barbosa Rodrigues displayed his international contacts. He paid homage to naturalists from around the world with whom he exchanged information, such as Édouard Beccari the botanist of Florence, to whom he dedicated a species found among the Crichanás. He designated dammeriana for his friend Dammer from the Berlin Botanical Garden who focused on palm trees. He also paid homage to 
Thiselton Dyer, director of Kew Gardens. He designated hassleriana after Emile Hasseler for their joint work in Paraguay. And, among many others, Barbosa Rodrigues paid homage with his classifications to Émile De Wildeman, conservationist of the Brussels Botanical Gardens, and to Alfred Cognaux, then responsible for the orchids section in Flora. He named arechavaletana, another of his palms, after José Arechavaleta, his colleague and the director of the Montevideo Museum. ${ }^{66}$

Sertum palmarum brasiliensium was printed in two volumes and included I74 watercolours and texts in Latin and French with descriptions of 382 species of palm trees from 42 genera, of which 166 were considered new at the time. Printed in Belgium and funded by the Brazilian government, to Barbosa Rodrigues this was the climactic achievement of a career marked by controversy, disputes, and lack of institutional support. Despite all the Amazon Botanical Museum's difficulties, being appointed its director by the imperial government enabled Barbosa Rodrigues to create the first scientific institution in the Amazon. Being appointed director of the Botanical Garden of Rio de Janeiro in I 892 enabled Barbosa Rodrigues to pursue, at what would become the most important botanical institution in the

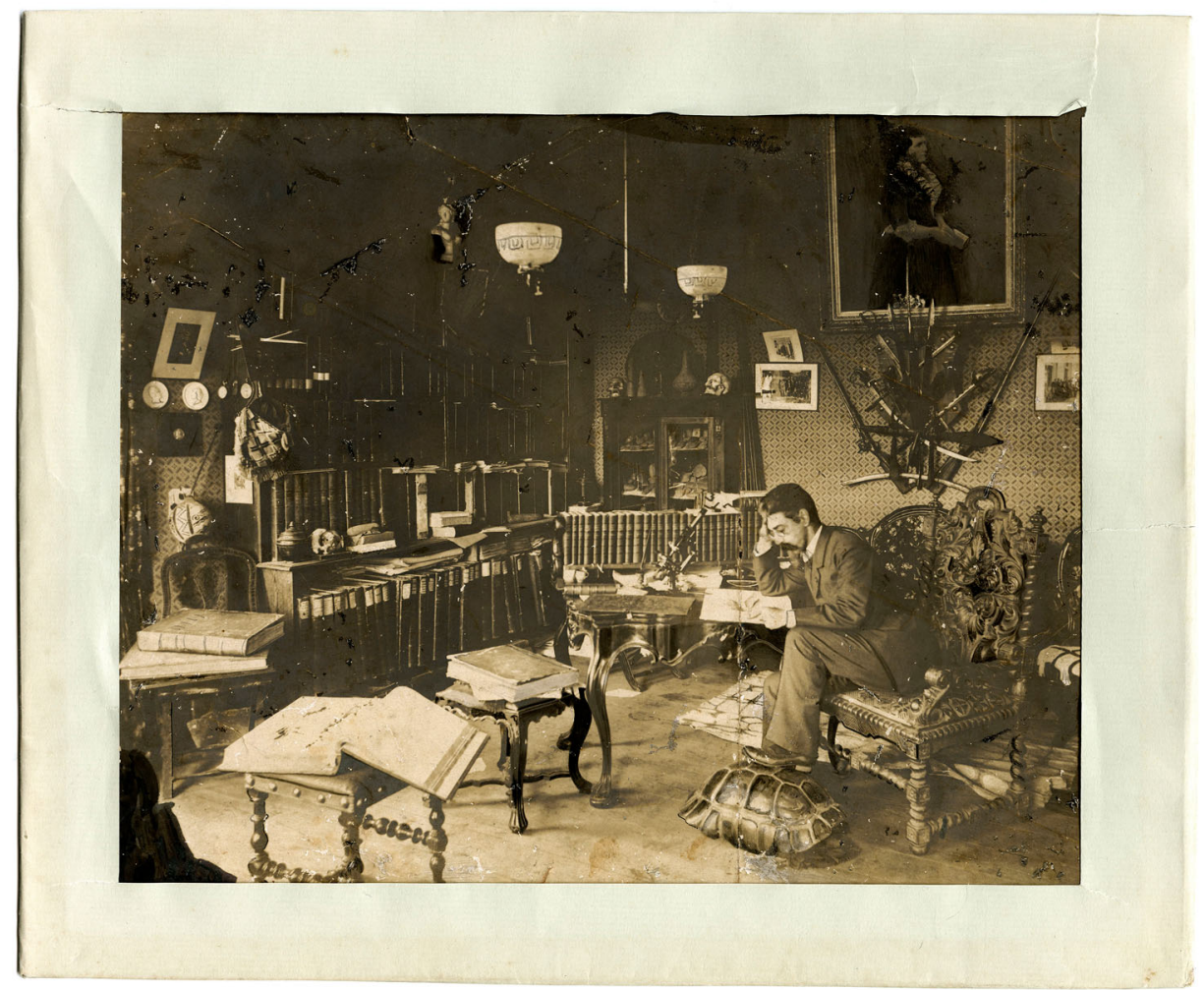

FIGURE 3 João Barbosa Rodrigues, director of Jardim Botânico do Rio de Janeiro, 1890 to 1909.

Courtesy of the Collection of Museu do Meio Ambiente. Jardim Botânico do Rio de Janeiro. Reproduced with permission. 
country, some of the projects he began at the Botanical Museum. ${ }^{67}$ The patronage of the Baron of Capanema, the experience he gained in the Amazon, and his ambition eventually transformed Barbosa Rodrigues into one of the most important Brazilian botanists. ${ }^{68}$ In charge of the Rio de Janeiro Botanical Garden, he became one of the most prestigious directors of the institution (Figure 3 ).

\section{Conclusion}

The goal of this article has been to show how the accomplishments and difficulties that marked the short existence of the Amazon Botanical Museum consolidated the scientific career of Barbosa Rodrigues. Perhaps the failure of the Museum reflects the intense competition among scientific institutions of that period. In the last decades of the nineteenth century the presence of science among the country's modernization projects was significant, but not free from contradictions. ${ }^{69}$ Brazil was and remains a country of continental dimensions marked by profound regional differences. To establish a modern scientific institution in the late nineteenth century dedicated to botany and ethnography required infrastructure, staff, the government's political vision, and the existence of a better structured scientific community, especially in a province in the heart of the Amazonian forest, far from the cultural support of Rio de Janeiro, the scientific centre of the country.

Despite the existence of several critical studies on the history of museums in Brazil, most attention has been paid to the 'uncomplicated story of [their] institutional progress' ${ }^{70}$ Describing the Museum's short life requires valuing the importance of such lost institutions. This task demands another perspective that embraces less heroic and less glorious models, that are perhaps less colourful than their enduring peers and that succumbed to the pettiness and whims endemic to the creation of scientific institutions and their practices. ${ }^{7 \mathrm{I}}$ As this article demonstrates, although the Amazon Botanical Museum was created with central government patronage, its survival was affected by opposition from the clergy, the press, provincial government officials, and finally Barbosa Rodrigues' own career and aspirations. At the end of nineteenth century, the word 'museum' - in Brazil and elsewhere - had different meanings. Museums fulfilled several functions that might include shaping civic identities. Whereas some historiographical approaches tended to conceive Brazilian museums as spaces for representing 'national', regional, or local 'identities', ${ }^{72}$ the Amazon Botanical Museum shows how a museum could be just one man's laboratory and his particular springboard for a scientific career.

\section{Notes}

I L. V. Coleman, The Museum in America. A Critical Study (Washington, DC: The American Association of Museums, 1939).

2 E. A. Williams, 'Art and Artifact at the Trocadero: Ars Americana and the Primitivist Revolution', in Objects and Others: Essays on Museums and
Material Culture, ed. by George W. Stocking Jr (Madison: University of Wisconsin Press, 1985), pp. I46-66; P. L. Kohl, I. Podgorny, and S. Ganger, Nature and Antiquities. The Making of Archaeology in the Americas (Tucson: The University of Arizona Press, 20I4), p. 5. 
3 See, for instance, O. A. Derby, 'The Present State of Science in Brazil', Science, I.8 (30 March I883), 2II-I4, which already mentions Barbosa Rodrigues' works, p. 2I4, <http ://www.jstor.org/stable/I7586I4? ?seq=I\#page_s can_tab_contents> [accessed I8 May 20I 5 ]. M. A. M. Dantes, S. F. de M. Figueirôa, and M. M. Lopes, 'Sciences in Brazil: An Overview from I870-1920', Boston Studies in the Philosophy of Science, 290 (20II), 95I05.

4 See in this volume Ceravolo's article 'Brazilian Ark: The Museum of the Instituto Geográfico e Histórico da Bahia (I 894-I927)'.

5 M. M. Lopes, O Brasil descobre a pesquisa científica: as ciências naturais e os museus no século XIX, 2nd edn (São Paulo: HUCITEC-UnB, 2009).

6 A. S. Blake, 'João Barbosa Rodrigues', Diccionario Bibliographico Brasileiro (Rio de Janeiro: Conselho Federal de Cultura, I970), pp. 359-65.

7 S. F. de M. Figueirôa, 'Ciência e tecnologia no Brasil Imperial: Guilherme Schüch, Barão de Capanema (I 824-I908)', Varia História, 2 I (2005), 437-55.

8 M. R. Sá, 'O botânico e o mecenas: João Barbosa Rodrigues e a ciência no Brasil na segunda metade do século XIX', História, Ciências, Saúde-Manguinhos, 8 (200I), 903.

9 K. Hill, Museums and Biographies. Stories, Objects, Identities (Woodbridge: Boydell Press, 2OI2).

IO Barbosa Rodrigues' biographies and participation and contribution in the Botanical Garden of Rio de Janeiro are comprehensively studied by Brazilian historiography. See, for instance, Rodriguésia, I 5 (I942) and Revista Brasileira de História da Ciência, 5 supl. (20I2).

I I M. R. Sá, 'O botânico e o mecenas', pp. 899924 .

I 2 J. B. Rodrigues, 'Base para a criação de um Museu Botânico na Província do Amazonas', in Relatório apresentado à Assembléia Legislativa provincial do Amazonas na abertura da segunda sessão da I 6 a legislatura em 25 de março de I883, ed. by José L. da C. Paranaguá (Manáos: Typ. do Amazonas, I 883 ), pp. $83-84$.

I 3 Vellosia. Contribuições do Museu Botanico do Amazonas I885-I888, I, II, III (Rio de Janeiro: Imprensa Nacional, I89I).

I4 J. B. Rodrigues, 'Regulamento para o Museu Botanico do Amazonas,' Vellosia, I ( I89I), iii-ix.
I5 Rodrigues, 'Regulamento para o Museu Botanico', pp. xiv and xvii-xviii.

I6 O Liberal do Pará, 26 February I 884, p. 2. This and all other references to the daily newspapers are in <http://bndigital.bn.br/hemerotecadigital/> [accessed I 8 May 20I 5].

I7 Museu Botanico, 'Obras Públicas. Relatório do estado e do andamento que tiveram as obras públicas da Província do Amazonas de I de janeiro a 3 I de dezembro de I884', Almanach Adm. Hist. Estatístico e Mercantil da Província do Amazonas (Manaus: Typ.do Amazonas, I 884).

I 8 J. C. Porto, 'Histórico do Museu Botânico do Amazonas', Vellosia, 2 (I89I), 6I-80.

I9 J. L. da C. Paranaguá, Relatório com que o Presidente da Província do Amazonas entregou a administração da mesma província ao Io vicepresidente Cel. Guilherme J. Moreira (Manáos: Typ. do Amazonas, I884).

20 The Crichanas (or Krichanás) are now identified as the Waimiri Atroari indigenous peoples. All names of indigenous nations mentioned in this article correspond to those used at the time.

2 I 'Padre Dacia contra os krichanás', Jornal do Amazonas, Io April I 886, p. 2.

22 J. B. Rodrigues, Rio Jauapery. Pacificação dos Crichanás (Rio de Janeiro: Imprensa Nacional, I 885 ), p. 274.

23 Porto, 'Histórico', p. 66.

24 J. B. Rodrigues, Relatório do Museu Botânico do Amazonas, 6 de julho de I885 ao Dr. J. J. Ferreira Junior, Presidente da Província do Amazonas (Manáos: Typ. do Amazonas, I 885 ).

25 'Museu Botanico', A Província, 6 August I 885, p. I.

26 J. B. Rodrigues, 'Catálogo da Seção Etnográfica e Arqueológica do Museu Botânico do Amazonas', Vellosia, 2 (I89I), 87-I 20.

27 Rodrigues, 'Catálogo da Seção Etnográfica', p. I23.

28 J. B. Rodrigues, Ídolo amazônico achado no rio Amazonas (Rio de Janeiro: Brown \& Evaristo, I875).

29 John Donnell Smith was a botanical researcher, graduating from Yale. He worked on the flora of Central America and especially in Guatemala. He donated his collections and library to the Smithsonian institution. Among his books on the Brazilian flora there are two descriptions of Barbosa Rodrigues' works on the Brazilian flora and structures of orchids referred as Botanical miscellanies, vol. II; A. C. Atwood, Catalogue of the botanical library of John 
Donnell Smith presented to the Smithsonian Institution, I908, p. 4, <http://www.jstor.org/ stable/2349I 555 ?seq=7\#page_scan_tab_con tents> [accessed I 8 May 20I 5]. The President of the Province refers to John Donnell Smith as 'his friend'. E. A. de V. Chaves, Relatorio com que o Presidente da Provincia do Amazonas, instalou a I.a sessão da I 8.a legislatura da Assembléa Legislativa Provincial no dia 25 de março de I 886 (Manáos: Typ. do Jornal do Amazonas, I 886$)$, p. I.

30 A. Houssay, '295 Catalogues of Precision Makers at the Bibliothèque Nationale de France, in Arranging and Rearranging: Planning University Heritage for the Future, ed. by Sofia Talas and Marta Lourenço (Padova: Padova University Press, 20I2), pp. I84-94.

3 I 'Notes and News', Science (30 July I 886), p. 99, $<$ http://www.jstor.org/stable/I 762060 ?seq= 3\#page_scan_tab_contents> [accessed I 8 May 20I5].

32 Biblioteca Nacional do Rio de Janeiro, Catálogo da exposição de História do Brasil (Brasília: Editora da UnB, I98I).

33 'Exposição', Jornal do Amazonas, 29 July, p. I; 3 August I886, p. I.

34 J. B. Rodrigues, Catálogo do Productos enviados para a Exposição de Berlim pela Província do Amazonas (Manáos: Typ. do Jornal do Amazonas, I 886).

35 The first chemist hired for the Laboratory was Joseph E. Aubert (n.d.), who only worked for a month, while another, Franz Pfaff (n.d.), introduced as a professor auxiliar from the University of Geneve, arrived in Manaus in I886. Disagreements between Pfaff and Barbosa Rodrigues, on the identification of an individual's blood at a crime scene in the context of the local political disputes, led to the separation of the Laboratory from the Museum and its almost closing in $\mathrm{I} 888$. Conego R. A. de Miranda, Exposição do que se passou na administração da Provincia do Amazonas ao Exmo.Sr. J. C. de Andrade, em I2 de julho de I 888 (Manáos: Typ. do Jornal do Amazonas, I888); O Liberal do Pará, 22 de julho de 1888, p. 2 . In this year, when the contract of the chemist ended, the Laboratory was reintegrated to the Museum.

36 Rodrigues, 'Descripção do Museu', p. 8I.

37 J. B. Rodrigues, 'Les reptiles fossiles de la Vallée de l'Amazone', Vellosia, 2 (I89I), 4I-54.

38 Rodrigues, 'Descripção do Museu', p. 82.
39 . J. B. Rodrigues, 'Explicação da Estampa do Laboratório', Vellosia, 2 (I89I), 85-86.

40 J. de O. Machado, Relatório com que o o presidente da Provincia do Amazonas instalou a a sessão extraordinária da Assembléia legislativa provincial em 2 de junbo de I889, Anexo F Museu Botanico do Amazonas, Manáos 15 de Maio de 1889 (Manáos: Typ.do Commercio do Amazonas, I 889), pp. 85-87.

4I See, for instance, Florentino Ameghino's work in Argentinean Museums. I. Podgorny, El sendero del tiempo y de las causas accidentales. Los espacios de la prehistoria en la Argentina, I850-I9IO (Rosario: Prohistoria ediciones, 2009).

42 J. B. Rodrigues, Sertum Palmarum Brasiliensium. Relation des palmiers nouveaux $d u$ Brésil (Bruxelles: Imprimerie Veuve Monnom, I903), p. 35 .

43 Rodrigues, 'Descripção do Museu', p. 83.

44 F. A. Monteiro, Relatório apresentado ao Exmo. Sr. Dr. Eduardo G. Ribeiro. Governador do Estado Federal do Amzonas pelo Diretor do Instituto Normal Superior, em 20 de junho de 1894 (Manaus: Typ. do Jornal do Amazonas, I894). The Amazon Museum is explicitly mentioned as the place of origin of the 'Indian fish arrows and bows and Indian canoes and paddles' in the Brazilian Commission, Catalogue of the Brazilian Section at the World's Columbian Exposition. Chicago ${ }^{2} 893$ (Chicago: E. J. Campbell, Printer, I893), p. 70. See also L. B. Bittencourt, 'Relatório apresentado ao Cidadão Dr. Eduardo G. Ribeiro pelo Representante do Amazonas na Exposição de Chicago', Diario Official. Estado Federado do Amazonas, 3 (May I 894), Io58.

45 W. A. Rodrigues, 'Barbosa Rodrigues e os estudos botânicos na Amazônia', RBHC, 5 (20I2), 22-30.

46 As belated recognition of its importance, the work was published by S. Sprunger, P. J. W. Cribb, and A. Toscano de Brito, João Barbosa Rodrigues - iconographie des orchidés $d u$ Brésil (Basel: F. Reinhardt Verlag, I996).

47 'The Flora brasiliensis was produced between I 840 and 1906 by Carl F. P. von Martius, August W. Eichler and Ignatz Urban, with the participation of 65 experts from different countries and taxonomic treatments of 22.767 species', <http://florabrasiliensis.cria.org.br/ index> [accessed I 8 May 20I 5]. 
48 Letter Reichembach to Regnell, Hamburg, 22 March I 877. J. Barbosa Rodrigues. Genera et species orchidearum novarum (Rio de Janeiro, C. et H. Feiuss, I877), p. v.

49 M. R. Sá and A. Heizer, 'O botânico Célestin Alfred Cogniaux e sua relação com o Brasil', in Brasil e Bélgica, cinco séculos de conexões e Interações, ed. by Stols L. P. Mascaro and C. Bueno (São Paulo: Narrativa-um, 20I4), pp. II3-I4.

50 Barbosa Rodrigues was involved in a controversy over the authorship of species with the Scottish botanist James William Trail (I 85 II9I9). M. R. Sá, 'James William Helenus Trail: A British Naturalist in Nineteenth Century Amazonia' (Ph.D. thesis, University of Durham, I996).

5 I J.B. Rodrigues, Anexo I2. Museu Botanico do Amazonas, Manáos 20 de agosto de I 888 . Conego R. A. de Miranda, Exposição, I888, Museu Botanico, pp. I-2.

52 Rodrigues, Vellosia, pp. I-75, 9I-I I 2, I I 5-33.

53 Rodrigues, Anexo I2. Museu Botanico do Amazonas, pp. I-2.

54 Rodrigues, 'Base para a criação de um Museu Botânico', p. 83 .

55 J. B. Rodrigues, 'Década de Strychnos Novos', Vellosia, I (I 885), 33-44.

56 J. B. Barbosa Rodrigues, L'Uiraêry ou curare. Extraits et Complément des notes d'un naturaliste brésilien (Bruxelles: Imprimerie Veuve Monnom, I903) ; M. R. Sá, 'Do veneno ao antídoto: Barbosa Rodrigues e os estudos e controvérsias científicas sobre o curare', RBHC, 5 (2OI2), I2-2I.

57 J. B. Rodrigues, O tamakoaré. Espécies novas da ordem das Ternstroemiaceas (Manáos: Typ. Jornal do Amazonas, I887), p. 28

58 J. B. Rodrigues, Ídolo amazônico (I875); J. A. da Fonseca, 'As estatuetas líticas do baixo Amazonas', in Arqueologia Amazônica, ed. by Edithe Pereira and Vera Guapindaia (Belém: Museu Paraense Emilio Goeldi, 20I0), pp. 235-57.

59 E. H. Giglioli, 'Lo studio dell'Etnologia al Brasille', Archivio per l'Antropologia e la Etnologia, 7 (I877), 40-46.

60 J. Langer, 'Ruínas e mito: a arqueologia no Brasil Império' (PhD diss., Universidade Federal do Paraná, 2000).

6I Rodrigues, 'Catálogo da Seção Etnográfica e Arqueológica', p. I I9.
62 Rodrigues, 'Antiguidades do Amazonas' Vellosia, pp. I-40; L. M. Ferreira, 'Território Primitivo: A Institucionalização da Arqueologia no Brasil (I870-I9I7)' (PhD diss., Universidade de Campinas, 2007).

63 H. von Ihering, 'João Barbosa Rodrigues', Revista do Museu Paulista, 8 (I9I I), 23-37.

64 J. B. Rodrigues, Muyraquitã e os Ídolos Symbólicos: Estudo da Origem Asiática da Civilização do Amazonas nos Tempos Prehistóricos, 2nd edn (Rio de Janeiro: Imprensa Nacional, I899).

65 Rodrigues, Sertum Palmarum Brasiliensium, book cover.

66 Rodrigues, Sertum Palmarum Brasiliensium, pp. 26, 64, 95, IOI, I02, IO9.

67 Barbosa Rodrigues brought the knowledge he had acquired with the Pariquis Indians of the Amazon on the use of a herbaceous plant of the family Nyctaginaceae. Used in liver treatment, the new drug was patented in 1893 by Barbosa Rodrigues as 'Pariquyna' in honour of the indigenous nation. The use of this medication was well accepted, broadly popular, and was commercialized until the I940s. Sá, 'O botânico e o mecenas', p. 9I 2.

68 S. A. Mori and F. C. Ferreira, 'A Distinguished Brazilian Botanist, João Barbosa Rodrigues (I842-I909)', Brittonia, 39.I (I987), 73-85; A. Henderson, The Palms of the Amazon (New York: Oxford University Press, I995); M. R. Sá, 'James William Helenus Trail', 1996, Revista Brasileira de História da Ciência, 5 (supl.) (20I2).

69 Dantes, et al., 'Sciences in Brazil', p. I03.

70 S. J. M. M. Alberti, Nature and Culture, Objects, Disciplines and the Manchester Museum (Manchester: Manchester University Press, 2009), p. I; Hill, Museums and Biographies, p. 2.

7 I I. Podgorny, 'Palabras Preliminares', in El desierto em uma vitrina. Museos e historia natural em la Argentina, I8IO-I890, ed. by Irina Podgorny and Maria Margaret Lopes, 2nd edn (Rosario: Prohistoria Ediciones, 2OI4), p. I3.

72 For a critical vision of this kind of approach, see L. F. Duarte, 'La nature nationale: entre l'universalisme scientifique et la particularité symbolique des nations', Civilisations. Revue internationale d'anthropologie et de sciences humaines, 52.2 (2005), 2I-44. 


\section{Notes on contributor}

Correspondence to: Maria Margaret Lopes, Faculdade de Ciência da Informação, Campus Universitário Darcy Ribeiro, Universidade de Brasília-Brasília, DF, 70.910-900. Email: mariamargaretlopes@gmail.com 